\title{
Seed and Information Exchange through Social Networks: The Case of Rice Farmers of Indonesia and Lao PDR
}

\author{
Gerlie Tatlonghari ${ }^{*}$, Thelma Paris ${ }^{1}$, Valerien Pede ${ }^{1}$, Inpong Siliphouthone ${ }^{2}$, Rita Suhaeti ${ }^{3}$ \\ ${ }^{1}$ International Rice Research Institute (IRRI), Metro Manila, The Philippines \\ ${ }^{2}$ National Rice Research Programme, National Agriculture and Forestry Research Institute, Vientiane, Lao PDR \\ ${ }^{3}$ Indonesian Center for Agro-Socio-Economic Analysis and Policy Studies, Indonesian Agency for Agricultural \\ Research and Development, Ministry of Agriculture, Jakarta, Indonesia \\ Email: "g.tatlonghari@irri.org
}

Received December $7^{\text {th }}, 2011$; revised January $8^{\text {th }}, 2012$; accepted February $9^{\text {th }}, 2012$

\begin{abstract}
The study investigates the structure of information exchange among men and women farmers who were involved in participatory varietal selection (PVS) on submergence-tolerant varieties in pilot communities in Lao PDR and Indonesia. The paper shows that network relationships influence the dissemination of new information on seed. In their decisions to adopt new rice varieties, farmers are strongly influenced by their kin and friends. The study also investigated social networks by gender in order to gain greater insights into how gender inequalities influence the effectiveness of social capital through social networks. Results show that information opportunities of men and women vary in terms of exposure to and control of information. These differences are mainly influenced by their social and cultural setting in rice farming systems and communities. The paper shows that gender should be accounted for when investigating the determinants of social networks. Factors affecting social networks differ by gender, and also across countries. For instance, older males in Indonesia tend to have larger social networks. Women who belong to large farming households tend to have bigger social networks. Generally, having more relatives is a good opportunity to increase social networks for males and females.
\end{abstract}

Keywords: Gender; Participatory Varietal Selection; Social Network Analysis

\section{Introduction}

Increasing rice production to ensure food security and increase incomes, especially in unfavorable rice areas, has been a growing concern of international and national agricultural research and extension systems (NARES) in Asia. For many years, scientists have been developing improved rice varieties and associated crop and resource management technologies for drought-, submergence-, and salt-affected rice areas. However, despite the availability of these technologies, much remains to be done in disseminating them to millions of poor rice farming communities in Asia. Technologies, particularly seeds of improved rice varieties, are disseminated through formal and informal channels such as social networks. Studies have shown that among poor rice farmers the diffusion of technology and adoption start in interpersonal network exchanges and social influences within the community as technology is passed on from one individual to another. However, understanding of these processes, particularly social networking, is often neglected and remains a gap related to socio-cultural determinants of technology adoption.

Past research clearly shows the role that social networks play in agricultural technology adoption. For instance, in Indonesia, Case (1992) states that rice farmers' decisions to adopt the use of a sickle is dependent upon neighboring farmers' success with using the sickle. Palis (2002) showed that the efficient use of existing social capital among farmers in a village led to the fast, sustained, and widespread use of integrated pest management

${ }^{*}$ Corresponding author.
(IPM). Again in Mozambique, Bandiera and Rasul (2006) reveal that sunflower farmers' adoption decisions are correlated to the choices of their network of family and friends. Most recently in Ghana, Conley and Udry (2010) discovered that pineapple farmers adjust their inputs to align with those of their neighbors who were successful in previous periods. Matuschke and Quaim (2007) analyzed the impact of social networks on the adoption of hybrid wheat in India and concluded that the results from a social network study could also provide extension agencies and agents with a new set of diagnostic tools that could fit well with the new extension emphasis on participatory and demand-driven extension approaches. However, research on the role of social networking in seed and information exchange on stress-tolerant rice varieties among rice farming households/individuals and also through a gender perspective is scant. By gaining awareness of existing information on exchange routes, information providers can act on information opportunities and make changes to information routes to improve the delivery of information services (Haythornthwaite, 1996). It is now increasingly recognized that information on agricultural innovations diffuses through social networks rather than being freely available in the village. We adhere to this view in studying the role that social capital may play in facilitating information exchange among rural households. Moreover, the roles of other end users of technologies, especially poor women farmers and their potential roles as key agents of change, can be tapped to accelerate the dissemination of rice and rice-related technologies.

In 2009, the International Rice Research Institute (IRRI) in collaboration with national agricultural research and extension 
systems (NARES) initiated the project "Development and dissemination of submergence-tolerant varieties" in six Southeast Asian countries frequently affected by typhoons and severely affected by floods, namely, Vietnam, Thailand, Cambodia, the Philippines, Indonesia, and Lao PDR. Within this project, a case study on "Seed and information exchange through social networks among men and women rice farmers" was conducted. This case study explored and compared the structure of information exchange among men and women farmers who were involved in PVS on submergence-tolerant varieties in pilot communities in Lao PDR and Indonesia. The study also investigated social networks by gender in order to gain greater insights into how gender differences influence the effectiveness of social capital in facilitating information exchange. In particular, this study examined the factors that affect the intensity of acquired social networks at the household level, while accounting for gender differentiation. Of interest to the study is whether these identified factors are the same for men and women.

\section{Social Networks and Gender}

Social concepts such as social networks and social capital have received a lot of interest when exploring the potential contribution of personal relationships in technology uptake. Social capital is deemed as important as other forms of capital such as financial, human, or natural. Networks facilitate communication, coordination, and the provision of information on the trustworthiness of individuals. Social networks can serve as a form of social capital - an important intangible component of individuals' and households' asset portfolios.

Gender analysis in Asian rice farming reveals that women in Southeast Asia contribute significantly in rice production and postharvest operations. Although labor participation in rice production varies by country, production systems, and other factors, women contribute about $46 \%$ and $60 \%$ in Indonesia and Laos, respectively (Paris, 2009). In Laos, women took over the traditional roles of men in rice farming, in which more than half of the rice farming activities such as transplanting, weeding, harvesting, and postharvest are dominated by women (Choulamany-Khamphoui, 2002). Similarly in Indonesia, women do most of the transplanting, weeding, and harvesting work (Sajogyo, 1985). Thus, women are seen to have a crucial role in shaping the rice economy of Laos and Indonesia.

Moreover, women do not just contribute to the physical assets of production but more importantly they seek new information and technology. Past studies in Nepal and other countries revealed that women are active seekers of information (Subedi $\&$ Garforth, 1996). Due to gender differences in roles and needs, men and women have differences in their selection criteria for rice varieties in the specific submergence prone areas (Paris et al., 2011). Although returns to men's and women's social capital may be identical, the responsiveness of household welfare to women's social capital is higher (Maluccio et al., 2003; Meinzen-Dick \& Zwarteveen, 2003). Rural women usually have less access than men to information and new technologies (FAO, 1997; Greenberg \& Okani, 2001; Mugniesyah, 2002; Hang Thi \& Van An, 2006; Katungi et al., 2006). They suffer from limited access to resources, markets, training, and decision-making opportunities. As a result, women seek formal and informal networks to cope with the shocks and to make sure that their views are represented, particularly if formal rules limit their participation (Meinzen-Dick \& Zwarteveen, 2003). Their lack of access to information and formal networks deprives them of their potential capacity to make informed decisions in effectively managing their farms and selling their farm products.

\section{Methodology and Estimation Procedures}

Identifying the role of social networks and the factors affecting them has been investigated in the literature under various methods. This type of research is placed under the umbrella of social network analysis (SNA). The recent literature on social network analysis supports evidence that social networks play a crucial role in information and innovation dissemination. Hence, knowing more about networks and their role will be beneficial for policy formulation.

When an individual decides to join a network, he/she has an expected utility that depends on some of his/her socioeconomic characteristics. This expected utility is assumed to be positive, which motivates individuals to join a network. Each individual has the choice of being connected to one, two, three, and more relatives or friends who constitute his/her "acquired social network." The intensity of the acquired network is therefore represented by a series of discrete household choices that could follow a Poisson or negative binomial distribution.

Following Katungi et al. (2007) in a similar study, we consider that the intensity of acquired social networks can be modeled as a series of discrete household decisions that sum across an aggregation of choices to a Poisson or negative binomial distribution. While the Poisson distribution assumes equality between the conditional mean and variance, the negative binomial is more suited to data exhibiting over-dispersion. The probability mass function of a Poisson distribution is given as:

$$
P(X=x / Z)=\frac{e^{-\lambda} \lambda^{x}}{x !} ; x=0,1, \cdots ; 0 \leq \lambda<\infty
$$

where $\lambda$ is the mean parameter that is also equal to the variance, and $Z$ a vector of covariates. The probability distribution of the negative binomial is given as:

$$
\begin{aligned}
P(X=x / Z) & =\left(\frac{r}{r+\lambda}\right)^{r} \frac{\Gamma(r+x)}{\Gamma(x+1) \Gamma(r)}\left(\frac{\lambda}{r+\lambda}\right)^{r} ; \\
x & =0,1, \cdots ; \theta>0,0 \leq \lambda<\infty,
\end{aligned}
$$

where $\Gamma$ represents the gamma function, $\lambda$ is the mean parameter and the variance is expressed, and $\lambda+\lambda^{2} / \mathrm{r}$ with $\mathrm{r}$ is the dispersion parameter. For large values of $r$ (maintaining, $\lambda$ fixed), the negative binomial converges to a Poisson distribution. The negative binomial regression can be seen as an extension of the Poisson regression that accounts for over-dispersion in the data. The choice between the Poisson regression and negative binomial regression is based on the test on the over-dispersion parameter. Alternatively, it is possible to estimate both models and perform a likelihood ratio test to decide on the model that best fits the data.

We start our estimation with a pooled regression in which data for the two countries (Indonesia and Laos) are pooled together. A country dummy is used to capture country-specific differences. Next, we estimate the model for the sample of males and females. Finally, we estimate the model for each country individually, and also for the sample of males and females. In this regression analysis, the dependent variable is the social network (measured in terms of number of trusted friends to whom the household can talk closely or approach for any problem) while the hypothesized factors that influence social networks are gender of the respondent, age, years in school, household size, area cultivated, number of relatives, member- 
ship in organizations, and access to extension services and social institutions in the village.

\section{Data and Variables Used in the Econometric Estimation}

This SNA study uses cross-sectional data gathered through focused household surveys of rice farming households involved in the PVS trials under the project "Dissemination of submergence-tolerant rice varieties in Southeast Asia" implemented by IRRI in 2009. Data were collected by social scientists from farmer-cooperators in Indonesia (101) and Lao PDR (95) who were also cooperators of PVS at key sites. These key sites are located in the province of West Java, Indonesia, and in the provinces of Khammouane and Champassak in Laos.

Social capital is formed by participating in an organization or investing in social networks or both. In this particular study, accumulation of social capital through social networks received much attention as most of the seed and information exchange in studied areas are produced in an informal mode. To measure the intensity of participation in social networks of the farmers, the dependent variable is defined as the number of trusted friends to whom the household can talk closely or approach for any problem. This definition of a social network excludes relatives because they constitute a "given social capital whose formation may be beyond the influence of the decision maker" (Wintrobe, 1995 cited in Katungi et al., 2007). Instead, the number of relatives of a farmer in the village was included as an independent variable to serve as a proxy for social capital endowment. Household characteristics such as age, gender, education, and household size are factors that might affect farmers' social networking behavior.

\section{Social Networks and Gender Analysis}

This study was conducted in submergence-prone rice villages in Khammouane and Champassak provinces in Lao PDR and in West Java and South Sumatra in Indonesia. These villages or key sites suffer from major environmental stresses that lead to crop loss. Flooding was one of the major stresses experienced in their rice farming (Manzanilla et al., 2011). However, submergence was experienced on varying occasions and in varying severity. During the wet season of 2009 when the study was conducted, $94 \%$ of the farmers in Indonesia experienced flooding. In Lao PDR, $57 \%$ of the farmers experienced flooding in different stages of rice growth. Flooding was experienced mostly in the vegetative phase, particularly at the tillering stage right after transplanting. Some farmers experienced flooding at varying stages, while others experienced it as early as the seedling stage and in others' plots flooding occurred during the ripening stage. Submergence occurred normally for 6 - 8 days in Indonesia and Lao PDR. Lao farmers experienced the deepest flooding, with an average depth of $134 \mathrm{~cm}$ (Table 1).

Area cultivated. Farmers in Indonesia and Lao PDR cultivate an average of 1.3 and 1.14 hectares, respectively. In Indonesia, all the rice plots are located in lowlands. In Lao PDR, 68\% are located in lowlands and the rest are in midlands. A higher proportion of Indonesian farmers have more access to irrigation during the dry and wet seasons. Some farmers (41\%) have access to assured irrigation during the wet season. In Lao PDR, on the other hand, $99 \%$ are heavily dependent on rain during the wet season. In terms of crop establishment, farmers in Indonesia and Lao PDR use the transplanting method. Only 5\% in
Table 1.

Submergence conditions of farmers' plots under a farmer-managed trial in Indonesia and Lao PDR, wet season, 2009.

\begin{tabular}{lcc}
\hline \multicolumn{1}{c}{ Flooding duration } & $\begin{array}{c}\text { Indonesia } \\
(\mathbf{n = 1 0 1 )}\end{array}$ & $\begin{array}{c}\text { Laos } \\
(\mathbf{n = 9 5 )}\end{array}$ \\
\hline Farmers experience flooding (\%) & 94 & 57 \\
Phase of rice growth (\%) & & \\
Vegetative phase & 94 & 48 \\
Reproductive phase & 96 & 35 \\
Ripening phase & 0 & 20 \\
Average days of flooding duration & 8 & 6 \\
Average depth of standing water $(\mathrm{cm})$ & 79 & 134 \\
\hline
\end{tabular}

${ }^{*}$ There are multiple responses.

Lao PDR opt for direct seeding as a strategy when rains do not come on time.

Varieties grown. Varieties planted in farmers' fields are very diverse and some farmers plants 2 - 3 varieties in their plots. A higher proportion of farmers in Indonesia and Lao PDR, 81\% and $68 \%$, respectively, grow high-yielding varieties. However, some farmers in Lao PDR (17\%) still use traditional varieties such as Sanpatong, Inthala, and Dor rice, which are used for special products such as rice cakes. In Indonesia, $29 \%$ of the farmer-cooperators grow submergence-tolerant rice varieties such as INPARA 3 (IR70213-9-CPA-12-UBN 2-1-3-1), IR64Sub1 (IR07F102), and Swarna-Sub1 (IR05F101). A lower proportion $(2 \%)$ of Lao farmers planted different sets of submergence-tolerant varieties such as IR66876-11-NDR-1-1-1-1, PSBRc 68 (IRRI 119), and TDK1-Sub1 (IR07F289). These farmers received submergence-tolerant seeds through the PVS trials of the project (Table 2).

Household size, age, education, and gender. The sample households surveyed have a larger household size in Lao PDR (7) than in Indonesia (5). Women are generally younger than men. The majority $(75 \%)$ of households in Indonesia belong to the Jawa Reyang group, followed by Javanese and Sundanese ethnic groups. In Lao PDR, farmers belong equally to Lao Lum and Phouthai groups. Male farmers in both countries are 49 - 50 years old. There is wide disparity in access to education between

Table 2.

General characteristics of the farming systems in Indonesia and Lao PDR, wet season, 2009.

\begin{tabular}{ccc}
\hline Farm characteristics & $\begin{array}{c}\text { Indonesia } \\
(\mathbf{n}=\mathbf{1 0 1})\end{array}$ & $\begin{array}{c}\text { Lao PDR } \\
(\mathbf{n}=\mathbf{9 5})\end{array}$ \\
\hline Rice area (ha) & 1.30 & 1.14 \\
Land type (\%) & & \\
Lowland & 100 & 68 \\
Midland & 0 & 32 \\
Field type & & \\
Irrigated & 57 & 1 \\
Partially irrigated & 41 & 0 \\
Rainfed & 2 & 99 \\
Method of establishment & & 5 \\
Direct seeding & 0 & 95 \\
Transplanting & 100 & \\
Traditional & & 17 \\
HYV & 3 & 81 \\
Rice variety (2008-2009) (\%) & 68 & 2 \\
Submergence-tolerant & 29 & \\
\hline
\end{tabular}


men and women. Although men have an average of seven years in school, women have only four years. Men and women have more farming experience in Lao PDR (24 to 28 years) than in Indonesia (19 to 22 years). A high proportion $(91 \%)$ of the farmer respondents in Lao PDR own their own lands. In contrast, $43 \%$ of the farmer respondents in Indonesia are still tenants (Table 3).

Size of social networks. The size of social networks and frequency of engaging in different kinds of information exchange and village activities largely influence the social capital of an individual. Social capital among men and women varies for the two countries as the accumulation of social capital is also dictated by gender roles and culture for each country. As shown in Table 4, social networking and information exchange in Indonesia and Lao PDR are done mostly with friends within the village, where male farmers for both countries have a larger social network than female farmers. Lao men and women also rely heavily on their relatives within the villages. The number of relatives and friends of the farmers outside the village are generally higher in Indonesia than in Lao PDR, especially among women. These results reveal that male farmers are more mobile than female farmers in Indonesia. Because of customs, Indonesian women farmers do mostly reproductive activities,

Table 3.

Socioeconomic profile of farmer respondents in Indonesia and Lao PDR, wet season, 2009.

\begin{tabular}{|c|c|c|}
\hline Characteristics & $\begin{array}{c}\text { Indonesia } \\
(\mathrm{n}=101)\end{array}$ & $\begin{array}{c}\text { Lao PDR } \\
(\mathrm{n}=95)\end{array}$ \\
\hline Household size & 5 & 7 \\
\hline \multicolumn{3}{|l|}{ Respondents (\%) } \\
\hline Male only & 54 & 54 \\
\hline Female only & 46 & 27 \\
\hline Both & 0 & 19 \\
\hline \multicolumn{3}{|l|}{ Age (years) } \\
\hline Males & 50 & 49 \\
\hline Females & 48 & 44 \\
\hline \multicolumn{3}{|l|}{ Ethnic group (\%) } \\
\hline Javanese & 17 & 0 \\
\hline Sundanese & 8 & 0 \\
\hline Jawa Reang & 75 & 0 \\
\hline Lao Lum & 0 & 50 \\
\hline Phouthai & 0 & 50 \\
\hline \multicolumn{3}{|c|}{ Educational level (years in school) } \\
\hline Males & 7 & 7 \\
\hline Females & 4 & 4 \\
\hline \multicolumn{3}{|c|}{ Farming experience (years in farming) } \\
\hline Males & 22 & 28 \\
\hline Females & 19 & 24 \\
\hline \multicolumn{3}{|l|}{ Tenure status $(\%)$} \\
\hline Not owned & 43 & 9 \\
\hline Owned & 57 & 91 \\
\hline
\end{tabular}

Table 4.

Social capital indicators by gender in Indonesia and Lao PDR, 2009.

\begin{tabular}{ccccccc}
\hline & \multicolumn{2}{c}{ Indonesia } & & \multicolumn{2}{c}{ Lao PDR } \\
\cline { 2 - 3 } \cline { 5 - 6 } & Males & Females & & Males & Females \\
$(\mathrm{n}=55)$ & $(\mathrm{n}=46)$ & & $(\mathrm{n}=39)$ & $(\mathrm{n}=33)$ \\
\hline $\begin{array}{c}\text { Strong ties } \\
\begin{array}{c}\text { Number of relatives within the } \\
\text { village (average) }\end{array}\end{array}$ & 4 & 5 & & 11 & 10 \\
$\begin{array}{c}\text { Number of friends within the } \\
\text { village (average) }\end{array}$ & 12 & 6 & & 15 & 12 \\
$\quad \begin{array}{c}\text { Weak ties } \\
\begin{array}{c}\text { Number of relatives outside } \\
\text { the village (average) }\end{array}\end{array}$ & 3 & 1 & & 5 & 7 \\
$\begin{array}{c}\text { Number of friends outside the } \\
\text { village (average) }\end{array}$ & 10 & 2 & & 6 & 8 \\
\hline
\end{tabular}

which limit them in having contact with other people outside their village. In contrast, in Lao PDR, there seem to be no differences between males and females in terms of mobility.

Seed information exchange. During the survey interviews, male and female farmers were also asked about their seed information exchange. In Indonesia, both men and women farmers rely on their friends and neighbors within the village for seed information. Male farmers also mentioned co-farmers within the village, extension agents, and formal groups as their other main sources of information. None of the male Indonesian farmers received any information from their wives. Eleven percent of the female farmers mentioned their spouses as additional sources of information (Table 5).

Membership in formal organizations. Most of the farmers in Indonesia and Lao PDR belong to a formal group. Women are surprisingly actively involved in organizations, which are mainly farmers' organizations, credit groups, and women's groups. This means that women are now recognized as part of the workforce in the community. However, trends in civic engagement still show that few women are privileged to have access to different sources of information such as newspapers, printed publications, agricultural programs on radio and television, attendance at training events or seminars, and communication with extension agents. In some civic activities such as the use of modern technology such as the Internet and cellular phones, women in Lao PDR more frequently use them than men. However, it is important to note that these women are few in number and are mainly female household heads and wives of village leaders who have somewhat the same access as men farmers.

Involvement in social activities. Involvement in social activities of men and women farmers is still based on gender roles. Indonesian male farmers are expected to be in their mosque more frequently than women. In Lao PDR, where women are expected to give alms to the monks and offer prayers, women are seen in their temples more frequently ( 71 times in a year) than men. Moreover, since market places are where the households sell and buy food and other items, more women are seen in these places than men. Women's role within the households consumes most of their time; thus, they do not have much time compared with men to go to hang around places to chat and drink with their friends and neighbors after work. Also, more men attend village meetings as they are traditionally the decision-makers in their households and in their communities, particularly in Indonesia; whereas, in Lao PDR, both men and 
Table 5.

Major sources of information about new varieties for stress-prone environments by gender in Indonesia and Lao PDR, 2009 (percentage of responses).

\begin{tabular}{|c|c|c|c|c|}
\hline \multirow[b]{2}{*}{ Sources of information } & \multicolumn{2}{|c|}{ Indonesia } & \multicolumn{2}{|c|}{ Lao PDR } \\
\hline & $\begin{array}{l}\text { Males } \\
(\mathrm{n}=55)\end{array}$ & $\begin{array}{l}\text { Females } \\
(\mathrm{n}=46)\end{array}$ & $\begin{array}{l}\text { Males } \\
(\mathrm{n}=39)\end{array}$ & $\begin{array}{l}\text { Females } \\
(\mathrm{n}=33)\end{array}$ \\
\hline \multicolumn{5}{|l|}{ Informal source } \\
\hline Spouse (husband/wife) & 0 & 11 & 3 & 12 \\
\hline Member of the household & 2 & 3 & 5 & 3 \\
\hline Relatives within the village & 9 & 21 & 3 & 6 \\
\hline $\begin{array}{c}\text { Friends and neighbors within the } \\
\text { village }\end{array}$ & 22 & 20 & 21 & 18 \\
\hline Relatives outside the village & 2 & 0 & 3 & 3 \\
\hline Friends outside the village & 1 & 2 & 0 & 3 \\
\hline Co-farmers within the village & 11 & 13 & 3 & 3 \\
\hline Co-farmers outside the village & 2 & 2 & 0 & 0 \\
\hline Informal groups & 4 & 3 & 0 & 0 \\
\hline Village leaders & 6 & 3 & 36 & 45 \\
\hline Dealers/traders & 1 & 3 & 41 & 27 \\
\hline Others & 1 & 0 & 0 & 0 \\
\hline \multicolumn{5}{|l|}{ Formal source } \\
\hline Formal groups/associations & 12 & 10 & 0 & 0 \\
\hline Research institutions & 7 & 5 & 26 & 18 \\
\hline Government agencies & 1 & 0 & 3 & 0 \\
\hline Agents/extension officers & 17 & 2 & 0 & 0 \\
\hline \multicolumn{5}{|l|}{ Media } \\
\hline Community or local newspaper & 1 & 2 & 3 & 0 \\
\hline Publications (leaflets, posters) & 1 & 0 & 0 & 0 \\
\hline Radio & 0 & 0 & 3 & 0 \\
\hline Television & 2 & 0 & 0 & 0 \\
\hline
\end{tabular}

women farmers have the privilege to attend village meetings (Table 6).

Flow of information. Aside from sources of information, farmers were also asked whether they were passing along the information they received about new varieties. Male and female farmers from both countries usually pass along the information they receive to their friends and neighbors within the village with whom they can regularly talk because of their proximity to one another. In Indonesia, where women are more constrained to their houses to do more reproductive activities, the information they receive is passed along only to the members of their households, friends, and neighbors within the village. Lao women farmers, who are permitted to be more involved in farming, do not just pass along the information they receive to their household members but they also actively pass it along to their friends and neighbors within $(82 \%)$ and outside $(11 \%)$ their villages. These results can lead to some conclusions that women can be as active as men farmers in information exchange if they are given the opportunity to be educated and trained (Table 7).
Table 6.

Source of seed information exchange.

\begin{tabular}{|c|c|c|c|c|}
\hline \multirow[b]{2}{*}{ Sources of information } & \multicolumn{2}{|c|}{ Indonesia } & \multicolumn{2}{|c|}{ Lao PDR } \\
\hline & $\begin{array}{l}\text { Males } \\
(\mathrm{n}=55)\end{array}$ & $\begin{array}{l}\text { Females } \\
(\mathrm{n}=46)\end{array}$ & $\begin{array}{c}\text { Males } \\
(\mathrm{n}=39)\end{array}$ & $\begin{array}{l}\text { Females } \\
(\mathrm{n}=33)\end{array}$ \\
\hline Membership in organization (\%) & 92 & 67 & 58 & 81 \\
\hline \multicolumn{5}{|l|}{$\begin{array}{l}\text { Civic engagement } \\
\text { (frequency in a year) }\end{array}$} \\
\hline Read a newspaper & 58 & 0 & 28 & 11 \\
\hline $\begin{array}{l}\text { Read publications (agricultural } \\
\text { magazines, posters, leaflets) }\end{array}$ & 14 & 1 & 28 & 37 \\
\hline $\begin{array}{l}\text { Listened to agricultural program on } \\
\text { the radio }\end{array}$ & 63 & 35 & 102 & 54 \\
\hline Watched television & 63 & 29 & 87 & 67 \\
\hline $\begin{array}{l}\text { Used Internet to know more about } \\
\text { agricultural programs }\end{array}$ & 0 & 0 & 13 & 42 \\
\hline $\begin{array}{l}\text { Used cellular phone to talk about } \\
\text { rice farming }\end{array}$ & 37 & 1 & 10 & 28 \\
\hline $\begin{array}{l}\text { Participated in seminars/training } \\
\text { activities }\end{array}$ & 2 & 3 & 15 & 6 \\
\hline $\begin{array}{l}\text { Participated in field experiments } \\
\text { (PVS, demos) (\%) }\end{array}$ & 2 & 2 & 1 & 1 \\
\hline Communicated with extension agents & 32 & 5 & 12 & 6 \\
\hline \multicolumn{5}{|l|}{$\begin{array}{l}\text { Frequency of participation in } \\
\text { social activity in a year }\end{array}$} \\
\hline Weddings/celebration & 22 & 30 & 15 & 9 \\
\hline $\begin{array}{l}\text { Places of worship } \\
\text { (churches, mosques) }\end{array}$ & 342 & 133 & 40 & 71 \\
\hline Funerals & 18 & 6 & 11 & 7 \\
\hline Festivals & 5 & 11 & 16 & 10 \\
\hline Market places & 63 & 105 & 43 & 54 \\
\hline $\begin{array}{c}\text { Hang-around places } \\
\text { (for storytelling, drinking, etc.) }\end{array}$ & 116 & 0 & 36 & 17 \\
\hline General village meetings & 16 & 2 & 20 & 21 \\
\hline
\end{tabular}

Table 7.

Individual and groups to whom information was related by the information receiver by gender in Indonesia and Lao PDR, 2009 (percentage of responses).

\begin{tabular}{|c|c|c|c|c|}
\hline \multirow[b]{2}{*}{ Sources of information } & \multicolumn{2}{|c|}{ Indonesia } & \multicolumn{2}{|c|}{ Lao PDR } \\
\hline & $\begin{array}{l}\text { Males } \\
(\mathrm{n}=55)\end{array}$ & $\begin{array}{l}\text { Females } \\
(\mathrm{n}=46)\end{array}$ & $\begin{array}{l}\text { Males } \\
(\mathrm{n}=39\end{array}$ & $\begin{array}{l}\text { Females } \\
(\mathrm{n}=33)\end{array}$ \\
\hline \multicolumn{5}{|l|}{ Household member } \\
\hline Spouse (husband/wife) & 8 & 16 & 9 & 5 \\
\hline $\begin{array}{l}\text { Member of the household } \\
\text { Co-farmers }\end{array}$ & 3 & 4 & 16 & 21 \\
\hline Co-farmers within the village & 9 & 4 & 2 & 0 \\
\hline $\begin{array}{l}\text { Co-farmers outside the village } \\
\text { Friends and neighbors }\end{array}$ & 4 & 2 & 0 & 0 \\
\hline $\begin{array}{l}\text { Friends and neighbors within the } \\
\text { village }\end{array}$ & 55 & 42 & 95 & 82 \\
\hline $\begin{array}{c}\text { Friends and neighbors outside the } \\
\text { village }\end{array}$ & 1 & 0 & 7 & 11 \\
\hline
\end{tabular}




\section{Factors Influencing Acquired Social Capital}

Table 8 shows the factors that influence the intensity of acquired social capital based on regression analysis. The first set of columns labeled "pooled" shows the estimation results when data from the two countries are pooled together. The next two sets of columns show estimations for Laos and Indonesia, respectively. In all estimations, the likelihood ratio test on the null hypothesis that all coefficients are equal to zero is highly significant, supporting that the included variables globally influence the size of social networks. The likelihood ratio test on the over-dispersion parameter $r$ is also significant, indicating that the negative binomial regression approach fits the data better than the Poisson regression. The gender variable is significant in the pooled regression, indicating that men tend to have a larger social network on average than women. These findings are similar to those of Katungi (2006) and Katungi et al. (2006), who found that social capital is a key factor in information exchange and that, compared with women, men generally have better access to social capital and consequently to information on innovations. The gender variable, though, was not found to be significant in Lao PDR. However, in Indonesia, it is highly significant and the magnitude of the coefficient is about twice that of the pooled regression. Age appears to have a

Table 8.

Negative binomial regression of the factors affecting the size of social networks of farmer cooperators by gender in Indonesia and Lao PDR, wet season, 2009.

\begin{tabular}{|c|c|c|c|c|c|c|c|c|c|}
\hline & \multicolumn{3}{|c|}{ Pooled } & \multicolumn{3}{|c|}{ Laos } & \multicolumn{3}{|c|}{ Indonesia } \\
\hline & $\begin{array}{c}\text { All } \\
(\mathrm{n}=194)\end{array}$ & $\begin{array}{c}\text { Male } \\
(\mathrm{n}=98)\end{array}$ & $\begin{array}{l}\text { Female } \\
(\mathrm{n}=96)\end{array}$ & $\begin{array}{c}\text { All } \\
(\mathrm{n}=95)\end{array}$ & $\begin{array}{c}\text { Male } \\
(\mathrm{n}=43)\end{array}$ & $\begin{array}{l}\text { Female } \\
(\mathrm{n}=52)\end{array}$ & $\begin{array}{c}\text { All } \\
(\mathrm{n}=99)\end{array}$ & $\begin{array}{c}\text { Male } \\
(\mathrm{n}=55)\end{array}$ & $\begin{array}{l}\text { Female } \\
(\mathrm{n}=44)\end{array}$ \\
\hline \multirow[t]{2}{*}{ Constant } & $1.1005^{* * *}$ & $1.2112^{* * *}$ & $1.6453^{* *}$ & $2.6580^{* * *}$ & $2.5451^{* * *}$ & $2.2940^{* * *}$ & $0.2631^{* * *}$ & 0.2837 & 0.8713 \\
\hline & $(0.4056)$ & $(0.4992)$ & $(0.7268)$ & $(0.4690)$ & $(0.6196)$ & $(0.7792)$ & $(0.6643)$ & $(0.6863)$ & (1.4417) \\
\hline \multirow[t]{2}{*}{ Gender } & $0.5105^{* * *}$ & & & 0.0489 & & & $1.1206^{* * *}$ & & \\
\hline & $(0.1503)$ & & & $(0.1656)$ & & & $(0.2613)$ & & \\
\hline \multirow[t]{2}{*}{ Age } & 0.0055 & $0.0152^{* *}$ & -0.0129 & 0.0064 & 0.0064 & 0.0228 & 0.0074 & $0.0258^{* * *}$ & -0.0152 \\
\hline & $(0.0066)$ & $(0.0072)$ & $(0.0123)$ & $(0.0082)$ & $(0.0090)$ & $(0.0158)$ & $(0.0098)$ & $(0.0096)$ & $(0.0201)$ \\
\hline \multirow{2}{*}{ Years in school } & 0.0186 & 0.0289 & -0.0403 & -0.0069 & -0.0001 & 0.0296 & 0.0154 & 0.0220 & -0.0183 \\
\hline & $(0.0207)$ & $(0.0229)$ & $(0.0440)$ & $(0.0224)$ & $(0.0282)$ & $(0.0420)$ & $(0.0365)$ & $(0.0313)$ & $(0.1297)$ \\
\hline \multirow{2}{*}{ Household size } & -0.0441 & -0.0588 & 0.0084 & -0.0366 & -0.0372 & -0.0621 & -0.0144 & -0.0440 & 0.0125 \\
\hline & $(0.0305)$ & $(0.0362)$ & $(0.0502)$ & $(0.0298)$ & $(0.0384)$ & $(0.0447)$ & $(0.0617)$ & $(0.0597)$ & $(0.1209)$ \\
\hline \multirow{2}{*}{ Area cultivated } & $0.0871^{* *}$ & -0.0556 & $0.1303^{* *}$ & -0.0793 & -0.1305 & 0.1410 & $0.1204^{* *}$ & -0.0525 & 0.1186 \\
\hline & $(0.0374)$ & $(0.0705)$ & $(0.0543)$ & $(0.0920)$ & $(0.1129)$ & $(0.1458)$ & $(0.0471)$ & $(0.0950)$ & $(0.0970)$ \\
\hline \multirow[t]{2}{*}{ Number of relatives } & $0.0390^{* * *}$ & $0.0326^{* * *}$ & $0.0534^{* * *}$ & $0.0307^{* * *}$ & $0.0275^{* * *}$ & $0.0355^{* * *}$ & $0.0812^{* * *}$ & $0.0359^{* *}$ & $0.1067^{* *}$ \\
\hline & $(0.0065)$ & $(0.0068)$ & $(0.0126)$ & $(0.0052)$ & $(0.0068)$ & $(0.0083)$ & $(0.0213)$ & $(0.0192)$ & $(0.0388)$ \\
\hline \multirow{2}{*}{ Membership in organizations } & 0.0210 & $0.2497^{* *}$ & -0.1271 & $-0.3801^{* *}$ & $-0.3211^{* *}$ & $-0.5017^{* *}$ & 0.0605 & $0.7330^{* * *}$ & -0.0842 \\
\hline & $(0.0908)$ & $(0.1329)$ & $(0.1113)$ & $(0.1538)$ & $(0.1725)$ & $(0.2705)$ & $(0.1232)$ & $(0.1791)$ & $(0.1672)$ \\
\hline \multirow[t]{2}{*}{$\begin{array}{l}\text { Involvement in social } \\
\text { activities }\end{array}$} & 0.0021 & 0.0083 & 0.0061 & 0.0007 & $0.0238^{* * *}$ & $-0.0877^{* * *}$ & 0.0012 & -0.0006 & 0.0465 \\
\hline & $(0.0081)$ & $(0.0078)$ & $(0.0222)$ & $(0.0125)$ & $(0.0144)$ & $(0.0282)$ & $(0.0114)$ & $(0.0087)$ & $(0.0404)$ \\
\hline \multirow[t]{2}{*}{ Extension } & 0.0034 & 0.0001 & 0.0124 & $0.0151^{* *}$ & $0.0114^{* *}$ & $0.0202^{* *}$ & -0.0001 & $-0.0045^{*}$ & -0.0973 \\
\hline & $(0.0022)$ & $(0.0020)$ & $(0.0114)$ & $(0.0070)$ & $(0.0122)$ & $(0.0087)$ & $(0.0026)$ & $(0.0022)$ & $(0.1156)$ \\
\hline \multirow[t]{2}{*}{ Country dummy } & $0.0066^{* * *}$ & $0.5594^{* * *}$ & $0.9335^{* * *}$ & & & & & & \\
\hline & $(0.1653)$ & $(0.2063)$ & $(0.2699)$ & & & & & & \\
\hline
\end{tabular}

Diagnostic tests

LR test all coefficients $=0$

\begin{tabular}{ccccccccccc} 
[Prob chi sq] & 0.0000 & 0.0000 & 0.0000 & 0.0000 & 0.0000 & 0.0000 & 0.0000 & 0.0000 & 0.0510 \\
alpha & 0.6803 & 0.4554 & 0.8430 & 0.3726 & 0.2887 & 0.3514 & 0.9111 & 0.4190 & 1.7286 \\
& $(0.0824)$ & $(0.0712)$ & $(0.1698)$ & $(0.0602)$ & $(0.0655)$ & $(0.0868)$ & $(0.1709)$ & $(0.0999)$ & $(0.5606)$ \\
$\begin{array}{c}\text { LR test alpha }=0 \\
\text { [Prob chi sq(1)] }\end{array}$ & 0.0000 & 0.0000 & 0.0000 & 0.0000 & 0.0000 & 0.0000 & 0.0000 & 0.0000 & 0.0000 \\
Pseudo R $^{2}$ & 0.0737 & 0.0708 & 0.0958 & 0.0794 & 0.0968 & 0.0951 & 0.0726 & 0.0820 & 0.0734 \\
\hline
\end{tabular}

Notes: Standard errors of parameter estimates are in parentheses. Significance at the $1 \%, 5 \%$, and $10 \%$ level is signaled by ${ }^{* * *},{ }^{* *}$, and ${ }^{*}$, respectively. 
significant influence on social networks, at least for Indonesian males. The older males of this country tend to have a larger social network. The size of the area cultivated has a significant influence on social networks in the pooled regression and it was observed that women who belong to large farming households tend to have a larger social network. Country-wise regression analyses reveal that, in Indonesia, only area cultivated shows a significant effect on social networks. In all models, the number of relatives has a significant influence on social networks. Since relatives represent the initial endowment of social capital, this sort of result is expected. Although membership in organizations reduces the size of social networks in Laos, it has a positive effect for Indonesian males, who increase their social networks by joining organizations. Given that the variable "membership in organizations" does not capture the level of participation of individuals in an organization, the negative effect observed in Lao PDR could be because individuals are members of these organizations with no active involvement and this does not allow them to increase their social networks. Social skills contribute to increasing significantly the social networks of males in Lao PDR but have a reverse effect for females. In Lao PDR, males participate more than females in market places, festivals, drinking clubs, and village activities. For Laos in general, as well as the male and female samples, contact with an extension service contributes to increasing significantly the intensity of social networks. In general, households in Indonesia tend to have a larger social network that their Lao counterparts. This is also true when sample of males and females are considered.

\section{Conclusions and Implications for Technology Dissemination}

This study investigated the structure of information exchange among men and women farmers who were involved in PVS on submergence-tolerant varieties in Lao PDR and Indonesia. More specifically, this study assessed whether there is a difference in information exchange among men and women farmers when it comes to acquiring information about seed technology. Results indicate that the spread of seeds and knowledge on submergence-tolerant rice varieties can be enhanced by tapping existing social networks of men and women farmers. Regression analysis revealed that the hypothesized variables globally influence the size of social networks. The gender variable is significant in the pooled regression, indicating that men tend to have a larger social network on average than women. The gender variable was not found to be significant in Lao PDR, but in Indonesia it was highly significant and the magnitude of the coefficient was about twice that of the pooled regression. Moreover, it is observed that older males in Indonesia tend to have larger social networks. The same effect is noticed with area cultivated in Indonesia. Having more relatives increases social networks for both males and females. Overall, gender plays an important role in determining the factors that affect social networks. This paper provides evidence that the factors affecting social networks are not the same for males and females.

\section{REFERENCES}

Bandiera, O., \& Rasul, I. (2006). Social networks and technology adoption in Northern Mozambique. The Economic Journal, 116, 869-902. doi:10.1111/i.1468-0297.2006.01115.x

Case, A. (1992). Neighborhood influence and technological change. Regional Science and Urban Economics, 22, 491-508. doi:10.1016/0166-0462(92)90041-X

Conley, T. G., \& Udry, C. R. (2010). Learning about a new technology: Pineapple in Ghana. American Economic Review, 100, 35-69. doi:10.1257/aer.100.1.35

Choulamany-Khamphoui, O. (2002). Role and empowerment of rural women in the Lao PDR. The First Session of the Workshop on the Achievement of the World Food Summit Action Plan, Tokyo, 23-25 January 2002.

Food and Agriculture Organization (FAO). (1997). Gender: The key to sustainability and food security. Rome: FAO.

Greenberg, M., \& Okani, R. C. (2001). strengthening women's participation in decision-making at the local level in Mali. Washington DC: Office of Women in Development, Bureau for Global Programs, Field Support and Research, US Agency for International Development.

Haythornthwaite, C. (1996). Social network analysis: An approach and technique for the study of information exchange. Library and Information Science Research, 18, 323-342. doi:10.1016/S0740-8188(96)90003-1

Hang Thi, S., \& Van An, L. (2006). Creating opportunities for change: Strengthening the social capital of women and the poor in upland communities in Hue, Viet Nam. In R. Vernooy (Ed.), Social and Gender Analysis in Natural Resource Management, Learning Studies and Lessons from Asia. Ottawa, ON: International Development Research Centre.

Katungi, E. M. (2006). Social capital and technology adoption on small farms: The case of banana production technology in Uganda. Ph.D. Thesis, Pretoria: University of Pretoria.

Katungi, E., Edmeades, S., \& Smale, M. ( 2006). Gender, social capital and information exchange in rural Uganda. CAPRi Working Paper No. 59. Washington DC: International Food Policy Research Institute.

Katungi, E., Machethe, C., \& Smale, M. (2007). Determinants of Social capital formation in Rural Uganda: Implications for group-based agricultural extension approaches. African Journal of Agricultural Resource Economics, 1, 67-190.

Maluccio, J., Haddad, L., \& May, J. (2003). Social capital and household welfare in South Africa, 1993-1998. In: A. Quisumbing (Ed.) Household decisions, gender and development: A synthesis of recent research (pp. 145-152). Washington DC: International Food Policy Research Institute.

Manzanilla, D. O., Paris, T. R., Vergara, G. V., Ismail, A. M., Pandey, S. A., Labios, R. V., Tatlonghari, G. T., Acda, R. D., Chi, T. T. N., Duoangsila, K., Siliphouthone, I., Manikmas, M. O. A., \& Mackill, D. J. (2011). Submergence risks and farmers' preferences: Implications for breeding Sub1 rice in Southeast Asia. Agricultural Systems, 104, 335-347. doi:10.1016/j.agsy.2010.12.005

Matuschke, I., \& Quaim, M. (2007). What you grow is who you know? The impact of hybrid seed adoption in India. Unpublished discussion paper, Stuttgart: University of Hohenheim.

Meinzen-Dick, R., \& Zwarteveen, M. (2003). Gendered participation in water management issues from Water Users' Associations in Africa. In: A. Quisumbing (Ed.), Household decisions, gender and development: A synthesis of recent research (pp. 153-158). Washington DC: International Food Policy Research Institute.

Mugniesyah, S. S. M. (2002). Role and empowerment of rural women in food security: Indonesia case. Proceedings of the workshop on the roles and empowerment of rural women in food security. Tokyo, Japan FAO Association: Japanese Ministry of Agriculture, Forestry and Fisheries and FAO.

Palis F. (2002). The impact of social capital in technology sharing and learning on integrated pest management (IPM) in Central Luzon, Philippines. Unpublished Ph.D. Thesis. Los Baños: International Rice Research Institute.

Paris R. (2009). Women's roles and needs in changing rural Asia with emphasis on rice-based agriculture. Taipei: Food and Fertilizer Technology Center (FFTC).

Paris, T. R., Manzanilla, D. O., Tatlonghari, G. T., \& Labios, R. (2011). 


\section{G. TATLONGHARI ET AL.}

Guide in the conduct of participatory varietal selection (PVS) of submergence-tolerant rice. Los Baños: International Rice Research Institute.

Sajogyo, P. (1985). The impact of new farming technology on women's employment. In: Women in rice farming (pp. 149-168). Aldeshot: Gower Publishing Company; Los Baños: International Rice Research
Institute.

Subedi, A., \& Garforth, C. (1996). Gender, information and communication networks: Implication for extension. The Journal of Agricultural Education and Extension, 3, 63-74. doi:10.1080/13892249685300201 